\title{
El Desarrollo de un Mercado del Agricultor ${ }^{1}$
}

\author{
M.E. Swisher, James Sterns and Jennifer Gove ${ }^{2}$
}

\section{Resumen}

Muchos factores distinguen entre los mercados del agricultor excelentes y aquellos que son penosos. Este boletín incluye una descripción de ocho pasos fundamentales para el establecimiento de un buen mercado. Otras secciones describen los aspectos legales de la formación de un mercado del agricultor, incluyendo un ejemplar de los estatutos y reglas para un mercado, y proveen conexiones a otras fuentes útiles de información.

\section{Ocho Pasos Claves}

\section{Los recursos disponibles en la comunidad}

El apoyo de la comunidad es crítico para un mercado del agricultor. La acepción por parte de los residentes, del gobierno y de los negocios asegura que el mercado se considera un elemento positivo en la vida de la comunidad. Además de los factores no palpables, las buenas relaciones con el pueblo ayuda en formas muy concretas. Agencias gubernamentales y negocios locales puedan ayudar en la identificación de una localidad para el mercado, en la publicidad y con otros recursos.

\section{La localidad}

El seleccionar una buena localidad para el mercado es complicado. Los aspectos críticos incluyen proximidad a los clientes ó los lugares que ellos visitan con frecuencia, estacionamiento, protección del sol y de las lluvias, asientos ó lugares donde los clientes pueden descansar y conversar y espacios para otras actividades asociadas con el mercado, tales como música o teatro. La localidad también puede afectar el tipo y el costo de los seguros requeridos para el mercado.

\section{Los vendedores}

El trabajo más penoso puede ser conseguir el apoyo de los agricultores y otros vendedores para el mercado. Un buen mercado ofrece una mezcla de productos y servicios para atraer a los clientes. El lograr una variedad de productos y servicios es críticos al éxito. Muchas oficinas locales de extensión (al nivel del candado) mantienen listados de los agricultores del área. La cámara de negocios locales es otra fuente de sugestiones, principalmente para vendedores de artesanías y servicios. Luego de identificar los vendedores potenciales, es bastante probable que será necesario convencerlos de que participar en el mercado es una buena idea. Es importante proveer información

1. This document is FCS5257-Span, one of a series of the Department of Family, Youth and Community Sciences, Florida Cooperative Extension Service, IFAS, University of Florida, Gainesville FL 32611: First published: August 2003. English version reviewed by Millie Ferrer, Ph.D. and Amy Simonne, Ph.D., Department of Family, Youth and Community Sciences, and Al Wysocki, Ph.D., Department of Food and Resource Economics, Univeristy of Florida, Gainesville, FL, 32611. Please visit the EDIS Web site at http://edis.ifas.ufl.edu

2. M.E. Swisher, Ph.D., associate professor, Department of Family, Youth and Community Sciences, James Sterns, assistant professor, Department of Food and Resource Economics, and Jennifer Gove, Graduate Assistant, Department of Family, Youth and Community Sciences, University of Florida, Gainesville FL 32611. 
realística en cuando a las ganancias potenciales porque los vendedores

tienen que ser convencidos que el tiempo que se gasta en el mercado se recompensará.

\section{La publicidad}

Aunque parece ser obvio, la publicidad es altamente importante, especialmente para un mercado nuevo. La publicidad en radio público ó en periódicos locales es más barato que aquella en radio comercial ó en la televisión. No se debe olvidarse de la publicidad gratis. Muchas comunidades, escuela, iglesias y otras organizaciones locales divulgan boletines. Las secciones del periódico local que tratan de los alimentos, la jardinería y los eventos del fin de la semana son buenas oportunidades para hacer conocido el mercado. Si se puede lograr el interés de los escritores, ellos mismos pueden describir el mercado en sus artículos. De especial interés son eventos especiales asociados con el mercado, como la música. La participación de grupos locales, tales como grupos educativos ó religiosos, pueden contribuir a la viveza del mercado. Ejemplos de grupos con intereses apropiados para un mercado son los Master Gardeners (Jardineros Maestros) y Native Plant Society (Sociedad para las Plantas Nativas). Actividades para los niños, tales como los payasos y las jacas, son atractivos a muchas familias.

Actualmente muchos mercados se publican por medio del Internet. Al fin de este boletín se proveen conexiones con unas páginas del Internet de mercados del agricultor para ofrecer ideas para su desarrollo.

\section{Los estatutos y reglas}

Cualquier mercado tiene que desarrollar sus propios estatutos y reglas. Para un ejemplar de los estatutos y reglas para un mercado ver páginas 4-11 de este boletín. Este ejemplar está en Inglés y se base en los verdaderos estatutos y reglas de varios mercados en Florida. Este documento se provee para su uso y se puede hacer cualquier cambio necesario para que sirva para su mercado.

\section{Organización sin fines de lucro}

La gran mayoría de mercados son organizaciones sin fines de lucro. Para lograr esta designación es necesario cumplir con varias reglas estatales. En Florida, se debe contactar el Department of Revenue (Departamento de Tesoro Público): 1-800-352-3671 (sólo llamadas provenientes de Florida) ó 1-850-488-6800.

\section{7. $\quad$ El director del mercado}

Un mercado pequeño, con pocas vendedores y poco clientes, puede funcionar sin un director, y muchos mercados nuevos no puede contratar a un director al principio. Sin embargo, para asegurar el crecimiento del mercado es recomendable contratar a un director, aunque sea un puesto de tiempo parcial. Un mercado grande generalmente requiere un director tiempo completo.

\section{8. $\quad$ El seguro}

El tipo de seguro necesario para el mercado dependerá en muchos factores. Se debe consultar con un especialista para determinar los requisitos específicos del mercado.

El Farm Service Agency (FSA) del Departamento de Agricultura de los Estados Unidos (USDA) provee seguro contra desastres naturales; es decir la destrucción de infraestructura por huracanes, inundaciones u otros fenómenos naturales. Esta agencia también proporciona préstamos, alimentos gratis y subsidios para la conservación de recursos naturales para apoyar estabilizar los ingresos para las familias agrícolas. Una de sus metas principales es ayudar a los agricultores entender y aprovechar de los muchos programas federales disponibles. Hay oficinas de esta agencia por todo el país ( http://www.fsa.usda.gov/edso/).

El Risk Management Agency (RMA) del USDA suministra un seguro contra la pérdida de cosechas por razones fuera del control del agricultor, aunque se compra el seguro mismo de una agencia privada aprobado 


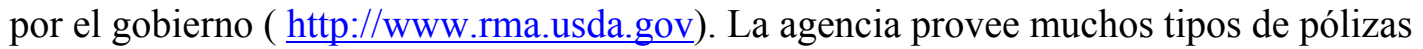
( http://www.rma.usda.gov/policies/). Para encontrar una lista de oficinas regionales, ver http://www3.rma.usda.gov/tools/agents/. La oficina para Florida se queda en Valdosta, Georgia.

Se debe considere la Florida Farm Bureau Federation, una organización de agricultores, para otros tipos de seguro. Los miembros de la federación pueden comprar seguros por sus agencias ( http://www.fb.org/flfb/).

\section{Otra Información Útil}

\section{Información sobre los Mercados del Agricultor}

En 20000, hubo aproximadamente 2,800 mercados del agricultor en los Estados Unidos, y se estima que unos 20,000 agricultores participan en los mercados. El número de mercados aumentó un 63 por ciento entre 1994 y 2000. El USDA ofrece mucha información en cuanto a los mercados del agricultor (http://www.ams.usda.gov/farmersmarkets/), incluyendo un listado de los mercados y recursos educativos para ayudar en el desarrollo de un mercado.

\section{Para los Clientes}

Un buen mercado del agricultor ofrece al consumidor una oportunidad de comprar alimentos producidos en el área. El número de consumidores que prefieren comprar directamente del agricultor crece conforme los clientes comprendan las ventajas. La compra de productos locales tiene efectos positivos no solamente para los agricultores, sino también para los clientes y las comunidades. IFAS provee un boletín, listo para fotocopiar y distribuir, que describe las ventajas de comprar alimentos producidos localmente: ( http://smallfarm.ifas.ufl.edu/Farmers\%20Market/consumer.pdf)

\section{Programas para la Seguridad Alimentaria}

Las metas del Food and Nutrition Service (FNS) del USDA son fortalecer la seguridad alimentaria y reducir la desnutrición. Este servicio provee cupones, otros tipos de asistencia alimentaria y programas educativos sobre la nutrición a los niños, los ancianos y las personas de bajos ingresos. Los agricultores y los mercados del agricultor tienen dos oportunidades para participar en estos programas.

Un agricultor tiene que ser certificado para aceptar los cupones federales para sus productos. Este proceso no es difícil (ver http://www.fns.usda.gov/fsp/retailers/default.htm), pero actualmente el FNS está cambiando del viejo sistema de cupones a un nuevo sistema basado en el uso de tarjetas plásticas (como una tarjeta de crédito). Como hay pocos mercados del agricultor que pueden ofrecer el equipo necesario para aceptar tarjetas de crédito, puede ser difícil participar en este programa. Sin embargo, el FNS está experimentando con la instalación del equipo en varios mercados del agricultor, incluso en Florida y pueda ser que se remueva esta barrera en el futuro.

El programa más grande de FNS se llama Women, Infants and Children (WIC). Este programa provee asistencia suplementaria de varios tipos, principalmente a las familias con niños jóvenes. (Ver http://www.fns.usda.gov/wic/ para una descripción general del programa). El FNS tiene dos programas específicos dentro del WIC para asegurar que sus clientes pueden comprar productos en los mercados del agricultor, uno para las familias con niños jóvenes y otro para los ancianos (ver http://www.fns.usda.gov/wic/FMNP/). El Departamento de Agricultura y Servicios para Consumidores (DACS) autorizan el uso de los cupones de WIC en los mercados del agricultor en Florida. El representante del DACS encargado de este programa es Carl Penn (850-487-4322 ó ver http://www.fl-ag.com/wicfmnp/). 


\section{Aspectos Legales del Mercadeo Directo al Consumidor}

Hasta el momento, el libro más útil y específico en cuanto a los aspectos legales de vender productos alimenticios directamente al consumidor es The Legal Guide to Direct Farm Marketing por Neil Hamilton. Este libro provee todo tipo de información para agricultores que quisieren vender directamente al público, incluso un capítulo completo que trata de los mercados del agricultor. Se puede conseguir el libro a un costo de \$20.00 del Drake University Agricultural Law Center, Des Moines, Iowa 50311 (para más información se puede llamar 515-271-2065 ó ver http://www.iowafoodpolicy.org/legalguide.htm).

\section{Licencia de Sanidad Pública}

Las leyes de muchos candados regulan la venta de productos pecuarios y procesados. La oficina local de extensión ó el departamento de salud del candado puede proveer información en cuanto a estas leyes locales.

\section{Bylaws and Rules}

\section{ARTICLE I - Name}

The name of this Corporation is the "Downtown Farmers' Market of Big Lake, Inc." and may be referred to in these Bylaws as the "Corporation."

\section{ARTICLE II - Purpose \& Objectives}

Section 1. The Downtown Farmers' Market of Big Lake, Inc. has been formed to provide healthy, fresh foods and horticultural products to Alligator County and surrounding areas, and to encourage commerce, entertainment and trade in Downtown Big Lake. (Mission Statement established June 1, 2001)

Section 2. To achieve its mission, the Corporation shall do the following:

a. Establish and operate a farmers' market for the purpose of furnishing a facility for sales of Florida fresh foods and horticultural products.

b. Work with the Alligator County Agricultural Extension Office/University of Florida (Institute of Food and Agricultural Sciences) and similar organizations to promote the production of Florida fresh produce and horticultural products in Vegetable County.

c. Organize and/or participate in educational and other activities that promote the use of Florida fresh produce and horticultural products.

d. Organize and/or participate in those activities that, in conjunction with the operation of a farmers' market, will serve to encourage commerce and trade in Downtown Big Lake.

e. Organize and/or participate in those activities that will serve to further the Corporation's mission.

f. Conduct research necessary to further the development of the farmers' market.

g. Solicit and receive funds, gifts, endowments, donations, devises and bequests.

h. Lease and/or purchase property necessary to further the mission of the Corporation.

Section 3. It is hereby provided that the said purposes are not intended to limit or restrict in any manner the powers or purposes of this corporation to any extent permitted by law, nor shall the expression of one thing be deemed to exclude another although it be of like nature.

Section 4. The Corporation is organized exclusively for public purposes as a not-for-profit corporation. Its activities shall be conducted in such a manner that no part of its net earnings will inure to the benefit of any member, director, officer or individual. In addition, the Corporation shall be authorized to exercise the powers permitted not-for-profit corporations under Chapter 617 of the Florida Statues as now exists or is subsequently amended or superseded provided, however, the furtherance of the exempt purpose for which it 
has been organized is as described in Section 501 (c)(3) of the Internal Revenue Code or any amendments or additions thereto.

Section 5. The Corporation shall be nonsectarian and nonpartisan.

ARTICLE III - Membership

Section 1. Any person interested in and who supports the purpose and objectives of the Corporation shall be eligible for membership.

Section 2. The membership of the Corporation shall be representative of a broad cross section of the community which it serves, including but not limited to representatives from business, citrus, government, horticulture, and education.

Section 3. Criteria for membership may be from time-to-time established by the Corporation Board of Directors.

\section{ARTICLE IV - Board of Directors}

Section 1. Except as otherwise provided for by law, by the Articles of Incorporation, or these bylaws, the Board of Directors shall exercise the powers of the Corporation, conduct its business affairs, and control its property. The Board is also expressly authorized to make appropriate delegations of authority through management agreements.

Section 2: The Board of Directors shall assume responsibility for setting goals of the corporation, reviewing and approving the Corporation's operational and strategic plans, and evaluating operational and strategic performance. No acquisitions or divestitures shall occur without prior approval of the Board.

Section 3: The Corporation Board of Directors shall be composed of fifteen (15) members.

Section 4: Five (5) members shall be elected each year to serve a three-year term.

a. By April 30 of each fiscal year, the Board of Directors will appoint a Nominating Committee which will be composed of not fewer than three (3) and not more than five (5) persons. Persons who might be considered to serve in one of the five (5) available Board positions may not be a member of the Nominating Committee.

b. By May 31 of each fiscal year, the Nominating Committee will present a slate of candidates numbering not fewer than five (5) and not more than ten (10) persons who are eligible to serve based on membership requirements found in ARTICLE III and who have expressed their commitment to serve as a member of the Board of Directors. In the preparation of the slate, the Nominating Committee shall consider the future composition of the Board of Directors for the purpose of having representation from a broad cross section of the community which the Corporation serves.

c. By June 30 of each fiscal year, the Board of Directors will elect five (5) persons to fill the five (5) available positions.

d. Those elected will begin their service on the July 1 that immediately follows their election.

e. A Board member may not serve more than two (2) consecutive three-year terms. 
Section 5. The Board of Directors shall establish attendance, participation and/or ethical standards, and may from time-to-time amend same, by which Officers and Directors will have to adhere to maintain their membership on the board.

Section 6. The Board of Directors may fill an unexpired term of an Officer or Director by a vote of fifty $(50 \%)$ percent plus one (1) of the Directors in attendance of a meeting at which a quorum is present.

Section 7. A quorum of the Board of Directors will be constituted with the presence of fifty (50\%) percent plus one (1) of the Board positions that are filled at the time of a meeting for which proper notice has been served.

Section 8. Notice of a Board of Directors meeting is to occur by written correspondence or facisimile and is to be received no less than seven (7) days prior to the meeting.

\section{ARTICLE V - Executive Committee}

Section 1. The Corporation Executive Committee shall have the full authority to act on behalf of the Corporation Board of Directors if action is required in a time which is insufficient to meet the notice requirement for calling a meeting of the Board of Directors, as found in ARTICLE IV, Section 8 of these bylaws. Otherwise, the Executive Committee shall act as an advisory, recommending body or in other capacities as may be determined by the Board of Directors. Actions taken by the Executive Committee on behalf of the Corporation shall be made known to the Board of Directors within seven (7) days from which the action was taken.

Section 2. The Corporation Executive Committee shall be composed of the following persons: Chairperson, Vice-Chairperson, Treasurer, Secretary and one (1) at-large member of the Board of Directors.

Section 3. The Board of Directors shall conduct an election to determine the Executive Committee members for the upcoming fiscal year during the period of time that immediately follows the annual election of Directors and the beginning of the new fiscal year on July 1.

Section 4. Persons eligible to serve on the Executive Committee must meet the membership requirements found in ARTICLE III of these bylaws and serve as a member of the Board of Directors.

Section 5. A quorum of an Executive Committee meeting will be constituted with the presence of fifty (50\%) percent plus one (1) of the Executive Committee members of which one (1) must be the Chairperson or ViceChairperson.

\section{ARTICLE VI - Officers}

Section 1. The Officers of the Corporation shall be the Chairperson, Vice-Chairperson, Treasurer and Secretary.

Section 2. Officers shall serve one (1) year terms and may not serve more than two (2) consecutive terms in any one position.

Section 3. It shall be the responsibility of the Chairperson to call and conduct all meetings of the Corporation Board of Directors and Executive Committee. The Chairperson will appoint, subject to the approval of the Board of Directors, the chairpersons of all Corporation committees. The Chairperson shall be the principal spokesperson for the Corporation and shall represent it at those programs and activities at which the Corporation is to have representation. 
Section 4. The Vice-Chairperson shall preside at meetings upon the absence of the Chairperson and shall assure the duties of the Chairperson upon his/her inability to fulfill the duties of his/her office as determined by the Board of Directors. The Vice-Chairperson shall serve as the Corporation's parliamentarian and shall be responsible to the Corporation to insure that the Corporations' business is conducted in an orderly fashion. Unless otherwise determined, meetings of the Corporation shall be conducted in accordance with Robert's Rules of Order.

Section 5. The Treasurer shall be responsible for providing a regular accounting of the Corporation moneys and financial transactions. The Treasurer shall be responsible for the prudent management of the Corporation moneys and for making the financial transactions necessary to conduct the business of the Corporation.

Section 6. The Secretary shall be responsible for notifying the members of the Board of Directors and Executive Committee of upcoming meetings. The Secretary shall be responsible for recording the actions taken by the Board of Directors and Executive Committee at their meetings. The Secretary shall be responsible for distributing correspondence and other information/material as may be necessary to conduct the business of the Corporation.

\section{ARTICLE VII - Committees}

Section 1. The Corporation Board of Directors shall from time-to-time form those committees deemed to be necessary to conduct the business of the Corporation.

Section 2. Persons to serve as a Committee Chairperson shall be members of the Board of Directors. Committee Chairperson shall serve as result of an appointment by the Corporation Chairperson and approval of the Board of Directors.

Section 3. Persons interested in serving as a member of a Corporation Committee shall be eligible to serve upon meeting the membership requirements found in ARTICLE III of these bylaws. It is not necessary for such persons to be a member of the Board of Directors.

\section{ARTICLE VIII - Staff Services}

The Board of Directors may from time-to-time engage an individual or organization to provide staff services to the Corporation. The Board will provide those so engaged with a scope of work, reasonable compensation, and periodic (not to be less frequent than once every twelve (12) months) evaluation of the efforts to accomplish the scope of work.

\section{ARTICLE IX - Finances}

Section 1. The Corporation shall use its funds only to accomplish the purpose and objectives specified in these bylaws, and no part of said funds shall inure to the benefit of nor be distributed to the members of the Corporation.

Section 2. The Corporation shall have a fiscal year beginning July 1 and ending June 30 of each calendar year.

Section 3. All moneys received by the Corporation shall be deposited to the credit of the Corporation in such financial institution or institutions as may be designated by the Board of Directors.

Section 4. The solicitation of funds shall not be authorized without prior approval of the Board of Directors. 
Section 5. No obligation of expenses shall be incurred and no money appropriated without prior approval of the Board of Directors.

Section 6. Upon approval of an annual budget, the Treasurer or other persons as authorized by the Board of Directors shall have the authority to make disbursements on accounts and expenses provided for in the budget without additional approval of the Board of Directors.

Section 7. Disbursements shall be made by check signed by the Treasurer and one other Officer.

Section 8. The Board of Directors may from time-to-time cause an audit to be conducted of the Corporation's books and accounts. Such audits are to be conducted by a certified public accountant, and upon its completion, the audit report shall be presented to the Board of Directors.

\section{ARTICLE X - Dissolution}

Upon dissolution of the Corporation, any funds remaining shall be distributed to one or more regularly organized and qualified charitable, educational, scientific, or philanthropic organization as selected by the Board of Directors.

\section{ARTICLE XI - Indemnification}

Each elected or appointed Director or Officer of the Corporation shall be indemnified by the Corporation against all expenses and liabilities, including counsel fees, reasonably incurred by or imposed upon him/her in connection with any proceeding or the settlement of any proceeding to which he/she may be a party or may be involved by reason of his/her being or having been a Director or Officer of the Corporation, whether or not he/she is a Director or Officer at the time such expenses are incurred, except when the Director or Officer is adjudged guilty of willful misfeasance or malfeasance in the performance of their duties. The foregoing right of indemnification shall be in addition to and exclusive of all other rights and remedies to which such Director or Officer may be entitled.

\section{ARTICLE XII - Waiver of Notice}

Whenever any notice is required to be given under the provision of Florida Statute, Articles of Incorporation or these bylaws, a waiver thereof in writing signed by the person entitled to such notice, whether before or after the same stated therein, shall be deemed equivalent to the giving of such notice where such waiver is permitted by Florida law. All waivers shall be filed with the Corporation records or shall be made a part of the minutes of the relevant meeting.

\section{ARTICLE XIII - Corporate Seal}

The Board of Directors may provide for a Corporate Seal in such a form and with such inscription as it shall determine provided such seal shall always contain the words "Corporation" and "Nor-for-Profit."

\section{ARTICLE XIV - Amendments}

These bylaws may be amended, altered, repealed or adopted by a 2/3rd vote of the Board of Directors at a meeting for which proper notice has been provided. 


\section{Rules for Downtown Farmers' Market of Big Lake, Inc.}

The Downtown Farmers' Market is intended to provide healthy, fresh produce and other assorted nutritional non-commercial foods to the residents of, and visitors to, the community and surrounding area. Both small and large vendors of produce and non-commercial food items will find a supportive outlet for the sale of their goods. The Market will encourage commerce, entertainment and trade in downtown Big Lake, and help display the city's history, uniqueness, charm and potential.

\section{MARKET RULES}

(IMPORTANT: Please read and sign the Market application. Return it, with your exhibit fee, to the Market Manager. Your signature indicates that you have read, understand and agree with the rules.)

\section{VENDOR EQUIPMENT AND SUPPLIES}

Each vendor is responsible for providing and removing any and all equipment and supplies he or she requires to do business on the Market site. This includes signs, tables, chairs, products and equipment utilized for clean-up purposes.

\section{SIGNS}

All signs must remain within the allotted vendor's exhibit space and must not block traffic or pedestrian ingress or egress, or interfere with other vendors' display or views.

\section{EXHIBIT SPACE}

Market management has full authority to assign exhibit space. Requests for particular sites will be given consideration but management reserves the right to assign and locate all vendors. Stall space will be assigned by 3:00 pm on the Friday preceding Market day for all vendors whose fees are paid by that time, and may be confirmed by calling 123-456-7899 between 3:00 pm and 5:00 pm on the Friday preceding Market day. (Please note this number has changed from last year.)

\section{HOURS OF OPERATION}

The Market shall operate every Saturday from 8:00 am - 12:00 noon. (**Please note the times have changed from last year.) All vendors must remain at the Market site until the 12:00 noon closing, and must vacate the Market site by 1:00 pm.

\section{SET-UP, CLEAN-UP AND BREAKDOWN}

Set-up starts at 7:00 am and must be completed by 8:00 am. Vendors are responsible for removing all garbage from their stall space area. Stall spaces are to be left in the same condition as when rented. Breakdown starts at 12:00 noon and must be completed, and stalls vacated, by 1:00 pm.

\section{PERMIT DISPLAY}

All vendors must display their permit pass in order to occupy a stall site. Permits shall remain on display during Market hours.

\section{VEHICLES AND PRODUCT DISPLAY}

Vehicles shall not be utilized as a display or dispensing area for Market goods unless it is a refrigerated unit for perishable items. No vehicle may remain running during Market hours other than for purposes of refrigeration of product. The use of canopies, awning and sun-umbrellas are encouraged. 


\section{PERMITTED MARKET ITEMS}

Fresh produce, plant items, flowers, baked goods, jellies, jams, preserves, and other non-commercial food items may be sold. No cooking will be allowed on-site. The Market Manager will resolve any doubt as to the suitability of an item. No soliciting or political or religious activities shall be permitted within the Market area. Displays of public interest, such as nutritional, health or consumer information, may be displayed with the permission of the Market Manager. All products must be sold, displayed and stored from a surface above the ground. All vendors must utilize tables, shelves, cases or other structures for these purposes.

FEES (All fees are utilized for publicity for the Market.)

Ten-foot $x$ ten-foot $\left(10^{\prime} x 10^{\prime}\right)$ stall spaces are $\$ 15.98$ including tax per Market day or $\$ 319.50$ including tax per Market season (October through April). Spaces with electricity are $\$ 21.30$ per Market day or $\$ 340.80$ per season. Vendors paying on a per Market day basis must pay their fee by 5:00 pm on the Thursday preceding Market day and pick up their display permit Market morning. Payment on a seasonal fee basis must be made prior to the first Market day of the Market season, as announced by the Market Manager. Seasonal fees may be pro-rated for vendors seeking to rent exhibit space after the Market season has commenced at the discretion of the Market Manager. No reimbursement will be made for fees paid if a vendor decides to no longer participate at the Market. The Market Manager shall consider reimbursement in case of illness or death. Vendors may call the Market at 123-456-7899 concerning Market closure due to inclement weather. Vendors shall be credited for fees paid if inclement weather causes cancellation of a Market day. Fees shall be waived for participants of the Community Gardens Program.

\section{MISCELLANEOUS}

Vendors are responsible for collecting and remitting their own sales tax. Vendors are responsible for all permits required by Florida or local County to sell their products. The sale or consumption of alcoholic beverages on the market site is prohibited. All rules may be revised by the decision of the Market Board.

\section{ENFORCEMENT OF RULES}

The Market Manager is responsible for enforcing the Market rules. Possible violations will be discussed and resolution attempted. Vendors selling prohibited items will be asked to remove those items from sale or leave the Market. Unresolved problems will be referred to the Market Board. Continued violations will result in being banned from the Market with no reimbursement of fees paid. Any vendor challenging another vendor's product's legitimacy or conduct must file a written complaint with the Market Manager, giving the name of the vendor and the product or situation they feel may not be in compliance with Market policies. The complainant must date and sign their name to the complaint and the Market Manager will attempt resolution. If resolution is not possible, the complaint will be referred to the Market Board.

\section{INSURANCE}

Vendors are encouraged to consider obtaining individual liability insurance for products sold.

\section{Mercados del Agricultor en el Internet}

\section{Programa de Mercados del Agricultor del Departamento de Agricultura de los Estados Unidos -} http://www.ams.usda.gov/farmersmarkets/ - Esta página del USDA provee un listado de los mercados del agricultor en cada estado, un boletín con información útil para el desarrollo de un mercado del agricultor, y otra información relevante a los mercados del agricultor. Se incluyen una sección para niños, un listado de recursos generales y información recién publicada por el USDA. 
Programa de Mercados del Agricultor de Florida - http://www.florida-agriculture.com/farmmkt/ - Esta página del Departamento de Agricultura y Servicios para el Consumidor incluye conexiones con los mercados estatales, un listado de los productos agrícola disponibles en el estado según estación, recetas para la preparación de productos floridanos, y información en cuanto al valor nutritivo de estos productos.

El Mercado del Agricultor Electrónico - www.farmersmarketonline.com - Esta página comercial provee un sitio donde los vendedores, productores y consumidores pueden contactarse. Se vende por el Internet alimentos no tradicionales, alimentos para animales y artesanías, además que los productos tradicionales de los mercados del agricultor.

El Mercado de Pike Place - www.pikeplacemarket.org - Este mercado en Seattle, Washington, es uno de los mejores conocidos en los Estados Unidos. Su página es un buen ejemplo de los tipos de información que un mercado puede ofrecer por el Internet, incluso la venta directa por el Internet.

El Mercado Original de Los Angeles - www.farmersmarketla.com - Otro mercado bien conocido y muy exitoso es él de Los Angeles. Su página incluye una breve historia del mercado, un directorio de los vendedores, estadísticas y publicidad general para el mercado. Esta página logró un premio del Los Angeles Times in 1996 por su calidad.

El Mercado de Olympia - www.farmers-market.org - El mercado de Olympia, Washington, también tiene fama. Su página incluye un listado de productos en venta por estación, noticias y un listado de vendedores con una descripción de cada uno.

El Mercado de Dane County - www.madfarmmkt.org - Este mercado se sitúa en Madison, Wisconsin. Se puede hacer un tour del mercado en la página del Internet y incluye una sección para niños, un listado de vendedores, un calendario y recetas para los productos vendidos en el mercado. Se destacan las características de un "vendedor especial" periódicamente y la "esquina para niños" ofrece actividades para jóvenes.

El Mercado de Dallas - www.dallasfarmersmarket.org - El mercado de Dallas, Texas, también acentúa un "vendedor del mes." Maestros de cocina bien conocidos ofrecen clases de cocina en el mercado mismo, las cuales se indican en la página del Internet como un modo de atraer clientes al mercado. Además del listado de vendedores y la breve historia del mercado, se incluye una descripción de las organizaciones comunitarias activas con el mercado.

El Mercado de Ithaca - www.ithacamarket.com - Ithaca es un pueblo universitario en el norte de Nueve York. Su publicidad en el Internet incluye una lista de preguntas y respuestas, formularios para solicitar espacio en el mercado, un calendario y una galería de fotos del mercado. Se proveen información sobre la historia del mercado y direcciones para llegar al mercado.

El Mercado de Bellingham - www.bellinghamfarmers.org - El mercado de Bellingham, Washington, está abierto desde abril hasta octubre. Su página señala las actividades que se llevan a cabo durante la estadía, un listado de vendedores (incluso dirección electrónica), y la solicitud para ser miembro del mercado.

El Mercado de Beaverton - www.beavertonfarmersmarket.com - Este mercado en Oregon se reconoce por una la revista Sunset and Country Gardens como un mercado del agricultor sobresaliente. Su información en el Internet incluye el listado de vendedores, una lista de contactos, la solicitud miembro y un boletín mensual. 